\title{
RĪGAS TEHNISKĀS UNIVERSITĀTES SVARĪGĀKO NOTIKUMU HRONOLOG̣IJA
}

\section{0./2021. STUDIJU GADS}

\section{0}

\section{1. septembrī}

RTU Inženierzinātṇu vidusskolā (IZV) notiek Zinību dienas pasākums, kurā piedalās izglītības un zinātnes ministre Ilga Šuplinska un viens no IZV atbalstītājiem, Rīgas Politehniskā institūta (RPI; tagad - RTU) absolvents (1986) uzñēmējs, AS «SAF Tehnika» valdes priekšsēdētājs Normunds Bergs.

http://www.izv.lv/2020/08/rtu-inzenierzinatnu-vidusskolu-1-septembri-apmeklesizglitibas-un-zinatnes-ministre-ilga-suplinska/

\section{2. septembrī}

RTU Materiālzinātnes un lietišksās ķīmijas fakultātes (MLĶF) Dizaina tehnoloǵiju institūta (DTI) absolvents Ilmārs Bērziņš 2020. gada konkursā «Ilgtspējība arhitektūrā, būvniecībā, dizainā» nominācijā «Ilgtspējīgākā studentu ideja 2020» iegūst otro vietu, DTI absolvente Nadīna Anija Poga - konkursa žūrijas atzinības nomināciju.

https://www.rtu.lv/lv/universitate/masu-medijiem/zinas/atvert/ rtu-dizaina-tehnologiju-studentu-darbi-apbalvoti-ilgtspejigu-ideju-konkursa

\section{7.-13. septembrī}

RTU IZV skolnieks Daniels Stabulis starptautiskajā ekonomikas olimpiādē iegūst sudraba medaḷu.

https://www.rtu.lv/lv/universitate/masu-medijiem/zinas/atvert/rtuinzenierzinatnu-vidusskolas-skolnieks-izcina-sudraba-medalu-starptautiskajaekonomikas-olimpiade

\section{1. septembrī}

Tradicionālā RTU rektora akadēmiķa Leonīda Ribicka tikšanās ar mācībspēkiem un studentiem, jauno studiju gadu sākot. Pirmo reizi pasākumu iespējams vērot arī tiešsaistē iekšējā RTU portālā ORTUS.

Pirmo reizi tiešsaistē notiek pirmkursnieku informatīvā diena «Startēšu RTU».

https://www.rtu.lv/lv/universitate/masu-medijiem/zinas/atvert/isi-pirmsakademiska-studiju-gada-sakuma-jaunos-studentus-tiessaiste-aicina-iepazit-rtu 


\section{4. septembrī}

Studenti tiekas tradicionālajos RTU Iezvanīšanas svētkos. https://www.rtu.lv/lv/universitate/masu-medijiem/zinas/atvert/ rtu-iezvanisanas-svetki-2020-1

\section{8. septembrī}

Godinot ķīmijas zinātnieci Emīliju Gudrinieci (1920-2004) un atzīmējot akadēmikses 100. dzimšanas dienu, «Latvijas Pasts» izdod jaunu pastmarku un aploksni.

https://www.pasts.lv/lv/zinas/filatelijas_zinas/5874-rigas-tehniskas-universitatesmaterialzinatnes-un-lietiskas-kimijas-fakultate-prezentes-kimikei-emilijaigudriniecei-veltitu-pastmarku

\section{9. septembrī}

Par Latvijas Studentu apvienības prezidenti ievēl RTU Arhitektūras fakultātes (AF) studenti Katrīnu Sprogi. https://www.delfi.lv/news/national/politics/latvijas-studentu-apvienibasprezidenta-amata-ievele-katrinu-sprogi.d?id=52484263

\section{4. septembrī}

RTU IZV šā gada absolvents Kārlis Šusters otro gadu pēc kārtas izcīna bronzas medaḷu starptautiskajā informātikas olimpiādē. https://www.rtu.lv/lv/universitate/masu-medijiem/zinas/atvert/rtuinzenierzinatnu-vidusskolas-absolvents-karlis-susters-izcina-bronzas-medalustarptautiskaja-informatikas-olimpiade

\section{8. septembrī}

Ar RTU Senāta lēmumu (sēdes protokola Nr. 642): nosaukums «RTU Goda absolvents 2019» pieškirts SIA «Latvijas mobilais telefons» prezidentam un valdes priekšsēdētājam Jurim Bindem;

Mašīnzinību, transporta un aeronautikas fakultātes (MTAF) dekāna amatā uz vēl vienu pilnvaru termiṇu apstiprināts profesors Ēriks Geriṇš.

\section{9. septembrī}

Ķīpsalā, Zunda krastmalā 10, notiek RTU Datorzinātnes un informācijas tehnologijas fakultātes (DITF) un koplietošanas auditoriju centra jaunās ēkas Spāru svētki.

https://www.rtu.lv/lv/universitate/masu-medijiem/zinas/atvert/ rtu-datorzinatnes-un-informacijas-tehnologijas-fakultate-svines-sparu-svetkus-1 


\section{Septembrī}

Prestižajā «The Times Higher Education (THE) World University Rankings 2021» RTU atzīta par 284. pasaules labāko universitāti, vērtējot augstskolu sadarbību ar industriju.

https://www.rtu.lv/lv/universitate/masu-medijiem/zinas/atvert/rtu-labakalatvijas-augstskola-finansejuma-piesaiste-no-industrijas?fbclid=IwAROKIkT9MMk-i7KnTysUk3T9gCZoHTJA2IrguwUPnqKvmQq26X $m s X_{-} U j G c$

\section{1.-2. oktobrī}

RTU atzīmē pasaules inženieru asociācijas dienu «IEEE diena». http://mttw.org/

\section{5. oktobrī}

Saistībā ar Latvijas Republika (LR) Saeimā virzītiem Augstskolu likuma grozījumiem, kas paredz augstskolu pārvaldības model̦a mainu, ieviešot padomes, RTU Satversmes sapulce vēršas LR Ministru kabinetā ar lūgumu pārcelt RTU rektora vēlēšanas un ațlaut tās organizēt ne vēlāk kā līdz 01.09.2021. Atbilstoši Ministru kabineta 27.01.2016. rīkojumam Nr. 38 «Par Rīgas Tehniskās universitātes rektora apstiprināšanu» RTU rektors Leonīds Ribickis amatā apstiprināts 02.02.2016. Augstskolu likuma 17. panta 2. punkts nosaka, ka augstskolas Satversmes sapulce rektoru ievēlē uz termiṇu, kas nepārsniedz piecus gadus.

\section{8. oktobrī}

Par Latvijas Zinātṇu akadēmijas (LZA) prezidentu ievēlēts RTU Goda doktors (2007) Ivars Kalviñš.

https://www.delfi.lv/news/national/politics/

par-zinatnu-akademijas-prezidentu-ievel-ivaru-kalvinu.d?id=52543663

LZA balvas iegūst divi RTU absolventi: Mg. chem. Mikus Puriņš par maǵistra darbu (darba vadītājs akadēmiḳis Māris Turks) saṇem Emīlijas Gudrinieces vārdbalvu; Dr. sc. ing. Andris Freimanis par promocijas darbu (darba vadītājs Dr. sc. ing. Ainārs Paeglītis) - Vitauta Tamuža vārdbalvu. RTU IZV skolotāja Dr. phys. Virgīnija Vītola saṇem LZA jaunā zinātnieka balvu.

https://www.lza.lv/aktualitates/jaunumi/208-lza-arkartas-pilnsapulce-tikapasniegtas-akademijas-vardbalvas-un-balvas-jaunajiem-zinatniekiem

\section{9. oktobrī}

Notiek tradicionālā RTU Vēstures diena.

https://www.rtu.lv/lv/universitate/masu-medijiem/zinas/atvert/

rtu-158-dzimsanas-dienas-svinibas-aizsaks-vestures-diena 


\section{2. oktobrī}

Godinot mūsu augstskolas dibinātājus un bijušos rektorus, RTU vadības un Studentu parlamenta (SP) pārstāvji, kā arī RTU IVPC apmeklē viṇu atdusas vietas Rīgas kapos.

\section{4. oktobrī}

Atzīmējot RTU 158. gadadienu, notiek RTU Senāta svinīgā sēde un 61. starptautiskās zinātniskās konferences plenārsēde.

https://www.rtu.lv/lv/universitate/masu-medijiem/zinas/atvert/ rtu-158-dzimsanas-diena-sumina-izcilakos-zinatniekus-un-macibspekus

Svinīgajās sēdēs apbalvo izcilākos, zinātniekus, mācībspēkus un sumina RTU Goda absolventu - par atbalstu inženierzinātņu studijām tituls «RTU Goda absolvents» piešksirts «LMT» prezidentam un valdes priekšsēdētājam Jurim Bindem.

Balvu «RTU Gada zinātnieks 2020» saṇem MLĶ,F dekāns akadēmiksis Māris Turks; balvu «RTU Gada jaunā zinātniece 2020» iegūst MLĶ, Vispārīgās k̦īmijas tehnoloǵijas institūta pētniece Līga Stīpniece; balvu «RTU Gada jaunais zinātnieks 2020» - Būvniecības inženierzinātṇu fakultātes (BIF) Materiālu un konstrukciju institūta vadošais pētnieks G̣irts Būmanis; Gada balvu valorizācijā saṇem BIF Transportbūvju institūta vadošais pētnieks Viktors Haritonovs; Gada studentu balvu valorizācijā - Elektronikas un telekomunikāciju fakultātes (ETF) Telekomunikāciju institūta doktorants un pētnieks Jānis Braunfelds. «Akadēmiskās izcilības Gada balvu 2020» saṇem Elektrotehnikas un vides inženierzinātṇu fakultātes (EVIF) Vides aizsardzības un siltuma sistēmu institūta direktore profesore Dagnija Blumberga; nosaukums «Gada jaunais mācībspēks 2020» piešksirts ETF Radioelektronikas institūta vadošai pētniecei Annai Litviṇenko.

Senāta svinīgajā sēdē sveic arī vairāk nekā 30 RTU mācībspēkus par jauno zinātnieku sagatavošanu, godina RTU IZV skolotājus, vairāki RTU darbinieki san,em RTU Goda diplomus.

https://www.rtu.lv/lv/universitate/masu-medijiem/zinas/atvert/ rtu-158-dzimsanas-diena-sumina-izcilakos-zinatniekus-un-macibspekus

Tradicionālajā «Būvindustrijas lielās balvas 2020» ceremonijā titulu «Gada students 2020» un naudas balvu san,em BIF students Raimonds Bagdanovičs un AF maǵistrants Raivis Jānis Mucenieks. Savukārt RTU saṇem uzñēmuma «Sakret» īpašo balvu «Kadru kalve».

http://lielabalva.lv/buvindustrijas-izcilniekiem-pasniegti-12-pamatakmeni/ 


\section{6. oktobrī}

Lai iepazītos ar RTU pētījumiem enerǵētikā, EVIF apmeklē Ekonomikas ministrijas delegācija, kuras sastāvā ir arī ekonomikas ministrs Jānis Vitenbergs.

https://www.rtu.lv/lv/universitate/masu-medijiem/zinas/atvert/ ekonomikas-ministrs-iepazistas-ar-rtu-petijumiem-energetika

\section{9.-23. oktobrī}

Aktualizējot diskusiju par ētikas ievērošanu akadēmiskajā vidē, RTU notiek Akadēmiskā godīguma nedēḷa, kurā, atzīmējot Starptautisko ètikas dienu un dienu cīnnai pret pasūtījuma darbiem, tiek atvērta arī RTU Akadēmiskā godīguma terminu vārdnīca.

https://www.rtu.lv/lv/universitate/masu-medijiem/zinas/atvert/ rtu-izdod-akademiska-godiguma-terminu-vardnicu

\section{3.-25. oktobrī}

MLĶF DTI studenti iegūst galvenās balvas skolu un augstskolu konkursā «Dizaina arēna 2020»: kategorijā «Gada labākais dizaina students» 1. vietu iegūst Marta Cimdina; 2. vietu - Svens Martulevs; kategorijā «Vides dizains» 1. vietu - Renāte Santa Gruzniṇa; 3. vietu - Elīna Leiba-Lipsne; bakalauru darbu sadal̦ā kategorijā «Dizaina pētniecība» 3. vietu - Ilmārs Bērziṇš; maǵistru darbu sadaḷā šajā kategorijā 3. vietu iegūst R. S. Gruznin,a.

https://www.rtu.lv/lv/universitate/masu-medijiem/zinas/atvert/ rtu-studentiem-pamatigs-balvu-klasts-konkursa-dizaina-arena-2020

\section{6. oktobrī}

Ar RTU Senāta lēmumu (protokola Nr. 643):

- $\quad$ Norvēgijas Dienvidaustrumu universitātes (University of SouthEastern Norway) asociētajam profesoram Rolfam Kvenildam (Rolf Qvenild) pieškirts RTU Goda biedra nosaukums;

- $\quad$ profesoram Jānim Mazajam piešksirts RTU emeritētā profesora nosaukums;

- apvienojot MTAF Transporta institūta Dzelzcel̦a automātikas un telemātikas katedru un Dzelzcel̦a transporta katedru, izveidota Dzelzcelıa inženierijas katedra.

\section{0. oktobrī}

Par sevišķiem nopelniem Latvijas valsts labā DITF profesoram, politiķim un bijušajam izglītības un zinātnes ministram (2002-2004; 2016-2018) Kārlim Šadurskim pieškkir Triju Zvaigžņu ordeni.

https://www.president.lv/lv/valsts-apbalvojumi/triju-zvaigznu-ordenis/jaunakiepieskirtie-apbalvojumi\#gsc.tab $=0$ 


\section{Oktobrī}

Prestižajā datubāzē «Web of Science» pirmo reizi indeksētas divas RTU zinātniskās monogrāfijas - «From Airplanes to Rockets - Friedrich Zander and Early Aviation in Riga» («No lidmašīnām līdz raķetēm - Frīdrihs Canders un aviācijas pirmsākumi Rīgā») un «Ernst Nauck (1819-1875). The First Director of Riga Polytechnicum» («Ernsts Nauks (1819-1875). Rīgas Politehnikuma pirmais direktors»). Abas monogrāfijas izdošanai sagatavotas RTU IVPC.

https://www.rtu.lv/lv/universitate/masu-medijiem/zinas/atvert/

prestizaja-datubaze-web-of-science-indeksetas-divas-rtu-zinatniskas-monografijas

RTU saṇem uzaicinājumu pievienoties starptautiskajai asociācijai «T.I.M.E.» (Top International Managers for Engineering).

https://www.rtu.lv/lv/universitate/masu-medijiem/zinas/atvert/rtu-sanemuzaicinajumu-pievienoties-prestizajai-starptautiskajai-asociacijai-t-i-m-e?fbclid=I wAR1AyvTw2psROxDth47LEtnIdUOnBaCHkIT8TKcV5diRxIwUVByGTZxLjEY

Baltijas Vadības attīstības asociācija piešksir balvu par novatorismu RTU Inženierekonomikas un vadības fakultātei (IEVF), novērtējot īstenoto starpdisciplinaritātes pieeju uzṇēmējdarbības izglītībā.

https://www.rtu.lv/lv/universitate/masu-medijiem/zinas/atvert/rtuinzenierekonomikas-un-vadibas-fakultate-inovativaka-fakultate-baltijas-jurasregiona

RTU starptautiskajā reitingā «Times Higher Education (THE) World University Rankings 2021 by Subject» inženierzinātṇu un datorzinātnes studiju jomā saṇem augstāko vērtējumu Latvijā.

https://www.rtu.lv/lv/universitate/masu-medijiem/zinas/atvert/rtu-timeshigher-education-reitinga-inzenierzinatnu-un-datorzinatnes-studiju-joma-sanemaugstako-vertejumu-latvija

\section{6. novembrī}

RTU pirmā no Baltijas valstu augstskolām paraksta Latvijas Dažādības hartu, tā apliecinot, ka atbalsta dažādību un vienlīdzīgas iespējas studiju un darba vidē.

https://www.rtu.lv/lv/universitate/masu-medijiem/zinas/atvert/

rtu-parakstis-dazadibas-hartu-apnemoties-ieverot-dazadibas-vadibas-principus

\section{0. novembrī}

DITF dekānam profesoram Agrim N,ikitenko pasniedz LR Zemessardzes Goda rakstu.

https://www.rtu.lv/lv/universitate/masu-medijiem/zinas/atvert/rtu-profesoramagrim-nikitenko-pasniedz-latvijas-republikas-zemessardzes-goda-rakstu 


\section{6. novembrī}

LZA pilnsapulcē par LZA īsteno locekli (akadēmiḳi) ievēlēts MLK,F profesors Jānis Ločs.

profesors-janis-locs-ievelets-par-latvijas-zinatnu-akademijas-isteno-locekli

\section{7. novembrī}

Valsts prezidents Egils Levits attālināti sveic RTU IZV skolēnus un absolventus - Džonatanu Miku Melgalvi, Danielu Stabuli, Edvardu Miķeli Mežciemu, Filipu Ēci, Kārli Šusteru un Ati Krebsu - un viṇu pedagogus Līgu Kamolu (ekonomika), Agru Lipsbergu (ǵeogrāfija), Lauru Fjdorovu (ḳimija) un Andreju Liepiṇu (programmēšana) - par sasniegumiem starptautiskās mācību olimpiādēs.

https://www.izv.lv/2020/11/valsts-prezidents-sveic-rtu-inzenierzinatnuvidusskolas-skolenus-un-skolotajus/?fbclid=IwAR3q4ITcGqNp9YEj89C s5F_OlLEg_l4LO78faZ44mIRIqokUEv5ykykPh3g

\section{0. novembrī}

Ar RTU Senāta lēmumu (protokola Nr. 644):

- $\quad$ EVIF dekāna amatā apstiprināts profesors Oskars Krievs;

- izveidots RTU Sadarbības koordinācijas centrs.

\section{Novembrī}

Piekto gadu pēc kārtas IEVF un RTU Rīgas Biznesa skola «Eduniversal» pasaules labāko biznesa skolu reitingā iekḷauta četru palmu līgā, kas apzīmē īpaši augstu akadēmisko līmeni, izcilu kvalitāti un spēcīgu starptautisko ietekmi biznesa un vadības izglītībā.

https://www.rtu.lv/lv/universitate/masu-medijiem/zinas/atvert/ rtu-biznesa-un-vadibas-izglitibai-nemainigi-augsts-starptautisks-novertejum $\underline{\underline{s}}$

Par ieguldījumu Ogres Centrālās bibliotēkas jaunās ēkas projekta virzībā, energobūvniecības nozares un tās profesionālās izglītības attīstībā Latvijā, kā arī par paveikto energoefektivitātes paaugstināšanā siltumapgādes sistēmās BIF profesoram Egilam Dzelzītim piešķir Ogres Goda pilson,a titulu.

http://www.ogrenet.lv/ogre/aktualitates/48437/

RTU vienīgā no Latvijas augstskolām iekḷūst starptautiskā reitinga «World's Universities with Real Impact» (WURI) sadal̦ā, kurā novērtēts universitātes ieguldījums uzṇēmējspēju veicināšanā.

https://lvportals.lv/dienaskartiba/322340-rtu-vieniga-no-latvijas-ieklust-reitingakura-novertets-universitates-ieguldijums-uznemejspeju-veicinasana-2020 


\section{6. decembrī}

IEVF students, Latvijas bobsleja pilots Dāvis Kaufmanis Eiropas kausa otrajā posmā Vācijā izcīna trešo vietu.

https://www.delfi.lv/sports/news/winter_sports/bobsleigh/

bobsleja-pilots-kaufmanis-eiropas-kausa-izcina-treso-vietu.d?id=52729959

\section{5. decembrī}

Latvijas valdība pien,em lēmumu par laboratorijas individuālo aizsardzības līdzekḷu akreditētai testēšanai izveidi. Jaunā laboratorija tiks veidota uz RTU bāzes, iesaistoties Rīgas Stradinna universitātei (RSU), īpaši - Darba drošības un vides veselības institūtam, Latvijas Biomedicīnas pētniecības un studiju centram, kā arī pārtikas drošības, dzīvnieku veselības un vides zinātniskajam institūtam «Bior». https://www.delfi.lv/news/national/politics/latvija-veidos-laboratorijuindividualo-aizsardzibas-lidzeklu-akreditetai-testesanai.d?id=52760479\&fbclid=I $\mathrm{w}$ AR1u1HwZS3bwsLyGqoZiiiRoYYLW2gOW-2iLOFXfPpkEDsj0P3Kxd4uBoY4

\section{9.-21. decembrī}

RTU komanda iegūst otro vietu Latvijas tiešsaistes čempionātā sporta bridžā.

https://www.rtu.lv/lv/sports/sporta-centra-jaunumi/atvert/rtu-komandaiotra-vieta-latvijas-tiessaistes-cempionata-sporta-bridza?fbclid=IwAR1foh7amtGmDfqLMc_HfbuNTHDJPPvw6FNHVwgvnRDJfBieq4hHrYP4Zo

\section{1. decembrī}

Ar RTU Senāta lēmumu (protokola Nr. 645) apstiprināta RTU Stratēǵija 2021.-2025. gadam.

\section{2. decembrī}

MLĶF DTI 1. kursa maǵistrante Marta Cimdiṇa izcīna 1. vietu jauno modes dizaineru konkursā «Modes manifestācija», balvā iegūstot tiesības ar savu kolekciju «Introvert Extraversion» pārstāvēt Latviju konkursā «Internationa Young Designers Contest 2021» Kijevā, Ukrainā, kas notiks nākamā gada jūlijā.

https://www.delfi.lv/kultura/news/culturenvironment/foto-jauno-dizainerukonkurss-modes-manifestacija-labaka-kolekcija-martai-cimdinai.d?id=52786009

\section{3. decembrī}

Par sasniegumiem starptautiskajās mācību priekšmetu olimpiādēs Ministru kabinets piešksir balvas RTU IZV skolēniem, absolventiem un vinu skolotājiem: IZV 12. klases skolēnam Džonatanam Mikam Melgalvim; IZV absolventam, MLĶF 1. kursa studentam Edvardam 
Mik̦elim Mežciemam; IZV absolventam, MLĶF 1. kursa studentam Filipam Ēcim; IZV absolventam, Kembridžas Universitātes 1. kursa studentam Kārlim Šusteram, kā arī skolotājām Laura Fjodorovai (k̦īmija) un Virgīnijai Vītolai (fizika).

https://www.rtu.lv/lv/universitate/masu-medijiem/zinas/atvert/rtuinzenierzinatnu-vidusskolas-skoleni-absolventi-un-pedagogi-sanem-ministrukabineta-balvas?fbclid=IwAR2t7GdoKWR1AAqreMtU1EYKEe60y1jiUeNj8 $5 N e_{-}$mHQV4YAIgkgdgQN28A

AS «Latvenergo» un LZA Gada balvas energèetikā saṇem EVIF jaunie zinātnieki un absolvents: Vides aizsardzības un siltuma sistēmu institūta vadošais pētnieks $\mathrm{Dr}$. sc. ing. Miķelis Dzirkevics; Energètikas institūta (EI) zinātniskais asistents Dr. sc. ing. Romāns Oḷekšijs; EI pētnieki Dr. sc. ing. Zane Broka, Dr. sc. ing. Kārlis Baltputnis un Dr. sc. ing. Ivars Zālītis; veicināšanas balvas saṇem Industriālās elektronikas un elektrotehnikas institūta zinātniskais asistents Dr. sc. ing. Jānis Mārks un EVIF absolvents Dr. sc. ing. Dmitrijs Sobolevskis.

https://www.rtu.lv/lv/universitate/masu-medijiem/zinas/atvert/rtu-jauniezinatnieki-sanem-latvenergo-un-latvijas-zinatnu-akademijas-gada-balvasenergetika

\section{Decembrī}

Latvijas modes māksliniece, MLĶF DTI absolvente Anna Elizabete Kasparsone iekḷauta izstādē Global Qipao Invitational Exhibition 2020, kas norisinās no 2020. gada rudens līdz 2021. gada oktobrim Hangžū, Ķīnā.

https://www.diena.lv/raksts/kd/maksla/latvijas-modesmaksliniece-anna-elizabete-kasparsone-ieklauta-starptautiskaizstade-kina-14252213?fbclid=IwAR2T9Mhxj2-TsJgzAa6aUZ SeWbhmuORDAYFN8rqwRPfUfHnje8ZxIRKnnO

RTU studenti 2020./2021. studiju gadā saṇem vislielāko Latvijas Sporta federāciju padomes Sporta stipendiju skaitu, salīdzinot ar pārējām Latvijas augstskolām.

https://www.rtu.lv/lv/universitate/masu-medijiem/zinas/atvert/rtu-studejosiesportisti-sanem-stipendijas-akademiskas-un-sportiskas-izaugsmes-sekmesanai

Pirmo reizi pasaules labāko biznesa skolu reitinga «Eduniversal» reputācijas vērtējumā IEVF un RTU Rīgas Biznesa skola saṇem augstāko novērtējumu Latvijā.

https://www.rtu.lv/lv/universitate/masu-medijiem/zinas/atvert/rtuinzenierekonomikas-un-vadibas-fakultate-prestizaka-biznesa-izglitibas-iestadelatvija 
Būtiski kāpinot savu pozīciju zaḷās politikas un ilgtspējas reitingā «GreenMetric», RTU atzīta par vienu 60 zal̦ākajām universitātēm pasaulē. https://www.rtu.lv/lv/universitate/masu-medijiem/zinas/atvert/ rtu-atzita-par-vienu-no-60-zalakajam-universitatem-pasaule

Starptautiskajā reitingā «RUR World University Ranking» RTU, salīdzinot ar pagājušo gadu, kāpina sniegumu vairākās pozīcijās. RTU joprojām ir vienīgā Latvijas augstskola, kas iekḷauta šajā reitingā.

https://www.rtu.lv/lv/universitate/masu-medijiem/zinas/atvert/rtu-kapinajusisavu-sniegumu-starptautiskaja-reitinga-rur-world-university-ranking

MLĶF profesoram Valdim Kamparam piešksir Pasaules Intelektuālā īpašuma organizācijas (WIPO) «Medaḷu izgudrotājam» (WIPO Medal for Inventors) par nozīmīgu ieguldījumu un inovatīvu darbību, radot izgudrojumus, īpaši biodegvielas jomā.

https://www.rtu.lv/lv/universitate/masu-medijiem/zinas/atvert/profesoravalda-kampara-ieguldijums-zinatne-novertets-ar-pasaules-intelektuala-ipasumaorganizacijas-medalu

RTU reitingā «QS ECCA 2021» visaugstāk novērtēta sadarbība ar darba devējiem.

https://www.rtu.lv/lv/universitate/masu-medijiem/zinas/atvert/ rtu-reitinga-qs-ecca-2021-visaugstak-noverteta-sadarbiba-ar-darba-devejiem 2020. gadā zaḷās politikas un ilgtspējas reitingā «GreenMetric» RTU ierindota 56. vietā.

https://labsoflatvia.com/aktuali/rtu-greenmetric-2020?fbclid=IwAR1FMUdIAPiFr kIKOBOq5dO7qncQzyWHQXyYPSPRzdYFIrO3TPsauDQMW5E

\section{1}

\section{5. janvārī}

N̦emot vērā 2020. gada 18. decembrī LR Saeimā pieñemtos grozījumus «Covid-19 infekcijas izplatības pārvaldības likumā», kas dod tiesības augstskolām, kurās laikā līdz 2021. gada 1. maijam atbilstoši ārējos normatìvajos aktos noteiktajiem termin,iem rīkojamas galveno lēmējinstitūciju vēlēšanas, RTU Satversmes sapulce pien,em lēmumu (sēdes protokola Nr. 31) atlikt RTU Satversmes sapulces, Akadēmiskās šksīrējtiesas, Senāta un RTU rektora vēlēšanas līdz 2021. gada 31. decembrim. Līdz jaunievēlēto augstskolas galveno lēmējinstitūciju pilnvaru spēkā stāšanās dienai minēto institūciju pilnvaras pilda iepriekšējās ievēlētās institūcijas, un līdz jauna rektora pilnvaru spēkā stāšanās dienai darbu turpina esošais rektors un esošie prorektori. 


\section{5. janvārī}

Eiropas kausa posmā bobslejā Īglsas trasē Insbrukā (Austrijā) IEVF studenta Latvijas bobslejista Dāvja Kaufmaṇa pilotētais četrinieks izcīna augsto 3. vietu.

https://bobslejs.lv/raksts/kaufmanis-pirmo-reizi-uz-pjedestalacetriniekos?fbclid=IwAR2k4Wrd_YAie1-HTm89_bd5H3vxlLaPjvZ7iNywN2b0oz1_ xmqr3hW3a-M

\section{9. janvārī}

MLK̦F Organiskās k̦īmijas tehnoloǵijas institūta zinātniskajam asistentam Jānim Miķelim Zaķim LZA piešķir Emīlijas Gudrinieces vārdbalvu ḳimijā.

https://www.rtu.lv/lv/universitate/masu-medijiem/zinas/atvert/emilijasgudrinieces-vardbalvu-kimija-pieskir-rtu-jaunajam-zinatniekam-janim-mikelimzakim

\section{1. janvārī}

LR Saeima piešķir Latvijas pilsonību RTU mecenātam, SIA «Mikrotīkls» (CEO Mikro Tik) līdzīpašniekam un valdes priekšsēdētājam Džonam Martinam Tallijam (John Martin Tully).

https://www.rtu.lv/lv/attistibasfonds/fonds-par-mums/zinas-1/atvert/ apsveicam-dzonu-martinu-talliju-ar-ieguto-latvijas-pilsonibu

\section{7. janvārī}

RTU vadība, studenti, mācībspēki un zinātnieki tiešsaistē tiekas ar izglīīibas un zinātnes ministri Ilgu Šuplinsku un Izglītības un zinātnes ministrijas (IZM) Augstākās izglītības, zinātnes un inovāciju departamenta direktoru Dmitriju Stepanovu, diskutējot par augstākās izglītības un zinātnes jautājumiem.

Atzīmējot Polijas-Latvijas diplomātisko attiecību 100. gadadienu, RTU rektors akadēmiķis Leonīds Ribickis saṇem Polijas Republikas vēstnieces Latvijā Monikas Mihališinas (Monika Michaliszyn) apsveikuma vēstuli un piemiñas medalu.

\section{Janvārī}

Par sasniegumiem zinātnē 2020. gadā LZA prezidenta Atzinības rakstus saṇem MLĶF trīs zinātnieku grupas: asociētais profesors Andris Šutka, vadošais pētnieks Kaspars Mālnieks, pētnieks Linards Lapčinskis un viṇu partneri Melburnas Universitātē (Austrālijā); profesors Valdis Kampars, vadošā pētniece Zane Ābelniece, vadošā pētniece Kristīne Lazdoviča, pētniece Lauma Laipniece, zinātniskā asistente Agija Stanke, pētniece Rūta Kampare, docente Elīna Sīle, vadošais pētnieks Modris 
Roze; MLĶ, Latvijas Universitātes (LU) Cietvielu fizikas institūta un Latvijas Organiskās sintēzes institūta apvienotā komanda - vadošā pētniece Irina Novosjolova, vadošais pētnieks Kaspars Traskovskis, pētnieks Armands Sebris, zinātniskais asistents Jānis Miḳelis Zaķis, zinātniskais asistents Andris Jeminejs, profesore Ērika Bizdēna, profesors Valdis Kokars un profesors Māris Turks, Mg. chem. Kristers Ozols, Mg. chem. Dace Cīrule, Mg. phys. Natālija Tetervenoka un Dr. phys. Anatolijs Mišñovs.

https://www.rtu.lv/lv/universitate/masu-medijiem/zinas/atvert/rtu-kimiki-sanemlza-prezidenta-atzinibas-rakstus-par-sasniegumiem-zinatne-2020-gada

\section{1. februārī}

Sveicot aktīvākos 2020. gada e-paraksta lietotājus, Latvijas Valsts radio un televīzijas centrs RTU piešķir apbalvojumu «eParaksta čempions 2020» un diplomu par iegūto trešo vietu. Pirmajā vietā portāls Latvija.lv, otrajā - Valsts ieṇēmumu dienests.

https://www.eparaksts.lv/lv/par_mums/Jaunumi/ eParaksts_tiek_lietots_videji_26_027_reizes_diena

\section{5. februārī}

Pulcējot pie ekrāniem studējošos, mācībspēkus, RTU vadības un fakultāšu pārstāvjus, tiešsaistē svinīgi nosauc un sveic RTU Studentu parlamenta Gada balvas 2020 laureātus.

https://www.rtu.lv/lv/rtusp/par-rtusp/sp-zinas/atvert/pgb2020-rezultati

\section{6. februārī}

RTU iegūst Latvijas Studentu apvienības Gada balvu divās nominācijās: par «Gada jauno zinātnieku 2020» atzìts ETF doktorants Jānis Braunfelds; nominācijā «Gada inovācija» balvu saṇem RTU iniciētā triecienprogramma «CrisisLab», kas izveidota sadarbībā ar LU, Latvijas Jūras akadēmiju, Liepājas Universitāti un Ventspils Augstskolu.

https://www.lsa.lv/notikusi-ikgadeja-lsa-gada-balva-par-studentu-lietu-atzitaakcija-gribustudet/

\section{0. februārī}

Eiropas kausa kopvērtējumā IEVF students, Latvijas bobsleja pilots Dāvis Kaufmanis iegūst 2. vietu divniekos. https://www.facebook.com/LVbsf/posts/3672047199577021

\section{6. februārī}

Tiešsaistē notiek RTU Atvērto durvju diena. https://www.rtu.lv/lv/universitate/masu-medijiem/zinas/atvert/ rtu-toposos-studentus-aicina-uz-atverto-durvju-dienu-tiessaiste 


\section{6.-28. februārī}

RTU studenti izcīna medaḷas starptautiskās sacensības peldēšanā «Latvian Open 2021», kas vienlaikus ir arī Starptautiskās peldēšanas federācijas (Fédération internationale de natation - FINA) oficiāli atzītas kvalifikācijas sacensības XXXII vasaras olimpiskajām spēlēm Tokijā. Daniils Bobrovs iegūst divas sudraba medaḷas (100 m un 200 m brasā), savukārt Artūrs Markovs - bronzas medaḷu (400 m brīvajā stilā). https://www.rtu.lv/lv/sports/sporta-centra-jaunumi/atvert/rtu-peldetajiemstarptautiskajas-sacensibas-sudraba-un-bronzas-medalas-atseviskas-disciplinas

\section{1. martā}

AF absolvente Una Île kḷūst par profesora Ivara Strautmaṇa Latvijas reǵionālās arhitektūras prēmijas laureāti.

https://www.rtu.lv/lv/universitate/masu-medijiem/zinas/atvert/profesora-ivarastrautmana-premiju-sanem-arhitekturas-fakultates-absolvente-una-ile

\section{4. martā}

Tiešsaistē notiek RTU Karjeras diena.

https://www.rtu.lv/lv/universitate/masu-medijiem/zinas/atvert/

rtu-aicina-jauniesus-piedalities-virtualaja-karjeras-diena

\section{5. martā}

RTU saṇem Aizsardzības ministrijas apbalvojumu nominācijā «Mācību iestāde «Izglītotājs par Zemessardzi»».

\section{6. martā}

Pirmo reizi RTU vēsturē doktorante Brigita Dal̦ecka vienlaikus aizstāv promocijas darbu Latvijā, RTU, un Zviedrijā, Zviedrijas Karaliskajā tehnologiju institūtā (KTH).

https://www.rtu.lv/lv/universitate/masu-medijiem/zinas/atvert/ pirmo-reizi-rtu-vesture-doktorante-aizstaves-promocijas-darbu-latvija-un-zviedrija

Itālijas Republikas vēstnieks Latvijā Viṇa ekselence Stefano Maria Taliani de Markio (Stefano Maria Taliani de Marchio) tiekas ar RTU rektora vietnieku starptautiskajā un akadēmiskajā sadarbībā Igoru Tipānu un Starptautiskās sadarbības un ārzemju studentu departamenta projektu vadītāju Ēriku Badamšinu. Tikšanās laikā izskatāmo jautājumu vidū ir arī iespējamā itālu valodas kursu izveidošana RTU (RTU studentiem un darbiniekiem), kas notiktu ar Ârlietu ministrijas un Itālijas Starptautiskās sadarbības finansiālu atbalstu.

https://www.rtu.lv/en/university/for-mass-media/news/open/icfsdand-the-ambassador-of-italy-to-latvia-discuss-the-establishment-ofitalian-language-courses-at-rtu?fbclid=IwAR10h52RyuRHxuoafoAYV8o G8q-y0X5Lw_kePwqg2zYB4t9ZqXSt2UiFHxM 


\section{Martā}

RTU uzlabo pozīciju prestižajā starptautiskajā reitingā «QS World University Rankings by Subject 2021», ierindojoties 201.-220. vietā labāko augstskolu vidū arhitektūrā, kā arī pakāpjas inženierzinātnēs un tehnologijās, iekḷūstot 401.-450. labāko pasaules augstskolu skaitā. https://www.rtu.lv/lv/universitate/masu-medijiem/zinas/atvert/ rtu-nostabilizejas-reitinga-starp-pasaules-vadosajam-inzenierzinatnu-augstskolam

Vairākas medal̦as Baltijas valstu čempionātā peldēšanā iegūst RTU studenti Daniils Bobrovs (IEVF) un Artūrs Markovs (MTAF), kā arī absolvents Girts Feldbergs.

https://www.rtu.lv/lv/sports/sporta-centra-jaunumi/atvert/rtu-peldetajivairakkart-kapj-uz-goda-pjedestala-baltijas-valstu-cempionata?fbclid=IwAROJg3D H7sJYcKNDC_A3jTtuk49sgyef7Bcrmwf8ekrhq8P8rzlSLhliGwM

RTU ierindojas 251.-300. vietā vienas no pasaules prestižākajām reitingu aǵentūrām «Times Higher Education» (THE) veidotajā jaunās ekonomikas valstu universitāšu reitingā «THE Emerging Economies University Rankigs 2021».

https://www.rtu.lv/lv/universitate/masu-medijiem/zinas/atvert/starptautiskajajaunas-ekonomikas-valstu-reitinga-augstu-noverte-rtu-starptautisko-sadarbibuun-ienakumus-no-industrijas

RTU otro reizi piešksirta «Erasmus» universitātes harta (ECHE - Erasmus Charter for Higher Education) «Erasmus+» programmas darbības periodam no 2021. līdz 2027. gadam.

https://www.rtu.lv/en/university/for-mass-media/news/open/

riga-technical-university-has-been-awarded-erasmus-charter-for-higher-education

\section{3. aprīlì}

Atklāj Baltijā pirmo 3D betona drukāšanas zinātnisko laboratoriju, to izveidojusi RTU sadarbībā ar SIA «Sakret».

https://www.rtu.lv/lv/universitate/masu-medijiem/zinas/atvert/ rtu-partneriba-ar-sakret-izveido-baltija-pirmo-3d-betona-drukasanas-laboratoriju

\section{9. aprīlī}

RTU rektors akadēmiķis Leonīds Ribickis un vides aizsardzības un reǵionālās attīstības ministrs Artūrs Toms Plešs tiešsaistē paraksta sadarbības memorandu par informācijas, prasmju un pieredzes apmaiṇu. https://lvportals.lv/dienaskartiba/327181-varam-sadarbosies-ar-lu-un-rtudigitalo-prasmju-integracijai-akademiskaja-vide-2021 


\section{9.-30. aprīlì}

Notiek tiešsaistes pasākums «Pieslēdzies RTU!», kas vidusskolēniem ḷauj iejusties RTU studentu ādā un uzzināt par studiju iespējām. Katra diena veltīta vienai no deviṇām RTU fakultātēm.

https://www.rtu.lv/lv/nac-studet/aktualitates-berniem-un-jauniesiem/ piesledzies-rtu

\section{0. aprīlī}

Latvijas Valsts prezidents Egils Levits un Ordenu kapituls nolemj: par sevišķiem nopelniem Latvijas valsts labā piešķirt Triju Zvaigžņu ordeni AF dekānam profesoram Uǵim Bratuškinam, ieceḷot profesoru par Triju Zvaigžṇu ordeña virsnieku; piešķirt Atzinības krustu ilggadējai RTU vēstures pētniecei profesorei Alīdai Zigmundei, ieceḷot profesori par Atzinības krusta komandieri.

https://www.rtu.lv/lv/universitate/masu-medijiem/zinas/atvert/rtu-arhitekturasfakultates-dekans-ugis-bratuskins-un-inzenierzinatnu-vestures-petniece-alidazigmunde-sanems-augstakos-valsts-apbalvojumus

\section{1. aprīlī}

RTU rektors akadēmiḳis Leonīds Ribickis paraksta atjaunināto «Lielo universitāšu hartu 2020».

https://www.youtube.com/watch?v=j923TMRXHhA\&t=9s

\section{2. aprīlī}

RTU Bērnu un jauniešu universitāte rīko pirmo starptautisko nodarbību Latvijas un Dānijas skolēniem, dodot startu projektam «Phereclos». Tā mērksis ir veicināt atvērtās skolas kultūru Latvijā, STEM (Science, Technology, Engineering and Mathematics - zinātne, tehnoloǵijas, inženierzinātnes un matemātika) izglītības pieejamību un jauniešu iesaisti zinātnē.

https://www.rtu.lv/lv/universitate/masu-medijiem/zinas/atvert/ rtu-sak-starptautisku-projektu-lai-veicinatu-stem-izglitibas-pieejamibu-berniem

\section{3. aprīlī}

RTU apmeklē Itālijas Republikas ārkārtējais un pilnvarotais vēstnieks Latvijā Stefano Maria Taliani de Markio (Stefano Maria Taliani de Marchio).

https://www.rtu.lv/lv/universitate/masu-medijiem/zinas/atvert/ italijas-vestnieks-latvija-iepazistas-ar-rtu-studiju-un-zinatnes-aktivitatem 


\section{9. aprīlī}

RTU Tautas deju ansambḷa «Vektors» mākslinieciskā vadītāja un horeogrāfe Dagmāra Bārbale Dejas balvas apbalvošanas ceremonijā kategorijā «Dejas notikums» iegūst LSM.lv balsojumā noskaidroto skatītāju simpātiju balvu par video darbu «Saules zīmē rotāties». https://www.rtu.lv/lv/kultura/par-mums-kultura/jaunumi-kultura/atvert/ sveiciens-visiem-dejotajiem-un-dejas-makslas-turetajiem-rtu-un-latvijastarptautiskaja-dejas-diena

\section{Aprīlī}

E-studiju tehnologiju un humanitāro zinātṇu fakultātes (ETHZF) students Heinrihs Cielavs izcīna uzvaru valodu uzñēmuma «Skrivanek Baltic» ikgadējā konkursā Latvijas augstskolu studentiem «Labākais jaunais tulkotājs 2021». RTU studente Maija Pokule konkursā iegūst trešo vietu.

https://www.rtu.lv/lv/universitate/masu-medijiem/zinas/atvert/ rtu-students-heinrihs-cielavs-atzits-par-2021-gada-labako-jauno-tulkotaju

RTU reitingā «Impact Rankings 2021» atzīta par 64. pasaulē labāko universitāti, kas cīnās pret klimata pārmaiṇām. Reitingā vērtētas 1115 universitātes no 94 valstīm.

https://www.rtu.lv/lv/universitate/masu-medijiem/zinas/atvert/ rtu-reitinga-impact-rankings-2021-atzita-par-64-pasaule-labakouniveristati-kas-cinas-pret-klimata-parmainam?fbclid=IwAR1D2vPtweFfdIn N41-SnabecpX9NZZOi_ibZBEg_yvET9QiO2BqBzLaE0A

Pirmo reizi visas IEVF maǵistrantūras studiju programmas iekḷautas prestižajā pasaules labāko biznesa skolu maǵistra studiju reitingā «Eduniversal Best Masters Ranking», apliecinot RTU piedāvātās izglītības starptautisko konkurētspēju un augsto darba devēju novērtējumu. https://www.rtu.lv/lv/universitate/masu-medijiem/zinas/atvert/visas-rtu-biznesaun-vadibas-izglitibas-magistra-studiju-programmas-ieklust-pasaules-top

Četri RTU studenti - trīs bobslejisti Lauris Kaufmanis (BIF), Dāvis Kaufmanis, Ralfs Bērziñš un skeletoniste Dārta Estere Zunte (visi IEVF) - iekḷauti Latvijas olimpiskajā vienībā, kas 2022. gada februārī startēs Ziemas olimpiskajās spēlēs Ķīnā, Pekinā.

https://www.rtu.lv/lv/sports/sporta-centra-jaunumi/atvert/cetri-rtu-studentiieklauti-latvijas-olimpiskaja-vieniba-kas-startes-ziemas-olimpiskajas-speles-pekina

\section{2. maijā}

Par RTU SP prezidenti ievēl IEVF studenti Anetu Tarasovu, kura iepriekš bija SP ārējo sakaru nodaḷas vadītāja.

https://www.rtu.lv/lv/rtusp/par-rtusp/sp-zinas/atvert/

arkartas-velesanas-ieveleti-atlikusie-valdes-locekli 


\section{3. maijā}

DITF atzīmē 60 gadu jubileju.

\section{5. maijā}

RTU Biznesa skolas direktors Jānis Grēviṇš kḹūst par Eiropas Inovāciju un tehnologiju institūta padomes locekli.

https://www.rtu.lv/lv/universitate/masu-medijiem/zinas/atvert/

rtu-rigas-biznesa-skolas-direktors-grevins-klust-par-eit-direktoru-padomes-locekli

\section{3.-14. maijā}

RTU studenti plūc uzvaras laurus starptautiskās sacensībās peldēšanā «Latvian qualification meet»: Daniils Bobrovs (MTAF) izcīna uzvaru 200 m peldējumā brasā; Artūrs Markovs (IEVF) iegūst zelta medalu 200 m un sudraba medaḷu 400 m distancēs brīvajā stilā; Atis Āre (BIF) izcīna bronzas medaḷ 50 m distancē uz muguras; savukārt RTU absolvents G̣irts Fedbergs izcīna zelta medaḷ 100 m peldējumā uz muguras un uzvaru kopvērtējumā.

https://www.rtu.lv/lv/sports/sporta-centra-jaunumi/atvert/rtu-peldetaji-izcinagodalgas-starptautiskajas-sacensibas-kipsalas-peldbaseina?fbclid=IwAROLHZ_ GZsTH9JeJje1y1Bh6-kZN8ZcY_TtjyXulEp9GnKSS5iarnHfTDJO

\section{5.-16. maijā}

IEVF 2. kursa students Artūrs Rinkevičs duetā ar Ardi Danielu Bedrīti izcīna sudraba medaḷu Eiropas U-22 čempionātā pludmales volejbolā.

https://www.rtu.lv/lv/sports/sporta-centra-jaunumi/atvert/rtu-

pludmales-volejbolistam-sudrabs-eiropas-u-22-cempionata?fbclid=IwAR15p2Ps9WLI3sW1-MXH5RrVBOTSSEeEfd1owOlySi9OriXTvT7CrJN 110

\section{1. maijā}

Notiek digitālais forums «Vai Latvijas izglītības sistēma sasniedz savu mērksi», ko organizē LR Saeimas Izglītības, kultūras un zinātnes komisija, Izglītības un zinātnes ministrija un RTU un kurā notiek ekspertu diskusijas par augstākās un profesionālās izglītības sasaisti ar darba tirgu. Katra foruma diena veltìta noteiktam tematam - pamatizglìtībai un vidējai izglītībai, augstākajai un profesionālajai izglīî̄bai, kā arī pieaugušo izglītībai un pārkvalifikācijai (pirmā diskusija - 21. maijā; otrā diskusija - 28. maijā; 3. diskusija - 4. jūnijā). https://www.rtu.lv/lv/universitate/masu-medijiem/zinas/atvert/ foruma-izglitibas-sistema-un-darba-tirgus-saturiskie-materiali 


\section{8. maijā}

Pateicībā par veiksmīgu sadarbību Nacionālo brun,oto spēku Jūras spēku komandieris jūras kapteinis Kaspars Zelčs pasniedz Atzinības rakstu RTU Liepājas studiju un zinātnes centra direktoram Mārcim Priedītim. https://www.facebook.com/Latvijasjurasspeki

\section{8.-29. maijā}

Desmito gadu pēc kārtas RTU notiek starptautiskā energèetikgu doktorantūras skola «10th International Doctoral School of Energy Conversion and Saving Technologies». Šogad skolas aktivitātes norisinās tiešsaistē.

https://ieei.rtu.lv/ids-ecst/

\section{1. maijā}

RTU Senāts pieṇem lēmumu (protokola Nr. 650):

- $\quad$ veikt grozījumus RTU Apbalvojumu un diplomu nolikumā, kas apstiprināts RTU Senāta 2019. gada 28. oktobra sēdē (protokola Nr. 633), papildinot ar Senāta lēmumu piešksiramo apbalvojumu klāstu ar apbalvojumu «RTU Goda profesors», ko nolemts pieškirt pensionētiem profesoriem par izcilu pedagoǵisko, zinātnisko un organizatorisko darbību RTU vismaz 10 iepriekšējo gadu laikā, un apstiprināt nolikumu «Par RTU Goda profesora nosaukuma piešksiršanu»;

- likvidēt MTAF Transporta institūta Autotransporta pētījumu un profesionālās kompetences centru.

\section{Maijā}

Apvienoto Nāciju Organizācijas (ANO) generālsekretārs Antoniu Gutērešs (Antonio Guterres) apstiprinājis 10 izcilu zinātnieku un pētnieku grupu, kas konsultēs, kā izmantot zinātni, tehnologijas un inovācijas, lai ātrāk sasniegtu ANO definētos Ilgtspējīgas attīstības mērķus. Viṇu vidū ir arī RTU zinātṇu prorektors akadēmiķis Tālis Juhna. https://www.rtu.lv/lv/universitate/masu-medijiem/zinas/atvert/rtu-prorektorstalis-juhna-konsultes-ano-ka-vairot-tehnologiju-potenciala-izmantosanu\%C2\%AO

MTAF saṇem vērtīgu uzṇēmuma «Instro» dāvinājumu mērinstrumentus Mašīnbūves un mehatronikas katedrai gandrīz astoṇu tūkstošu eiro vērtībā.

https://www.rtu.lv/lv/universitate/masu-medijiem/zinas/atvert/uznemumsinstro-davina-jaunus-merinstrumentus-rtu-masinbuves-un-mehatronikas-katedrai 
MLĶF DTI absolvente Nadīna Anija Poga izstrādā jauna dizaina Liepājas sabiedriskā transporta kontrolieru formas tērpus.

https://www.rekurzeme.lv/vietejas-zinas/liepaja/liepajas-sabiedriska-transportakontrolieriem-bus-jauna-dizaina-formasterpi-153311

RTU IZV komanda uzvar Baltijas Biomateriālu ekselences centra (Baltic Biomaterials Centre of Excellence - BBCE) erudīcijas konkursā skolēniem «BIO-GO-Higher», balvā iegūstot ceḷojumu uz Šveici un iespēju iesaistīties biomateriālu pētniecībā AO Pētniecības institūtā Davosā.

https://www.izv.lv/2021/05/

rtu-izv-komanda-uzvar-erudicijas-konkursa-bio-go-higher/

\section{1. jūnijā}

RTU vadošā pētniece Inga L̦ašenko saṇem Latvijas Drošības un aizsardzības industriju federācijas 2021. gada balvu izglītībā un pētniecībā.

https://www.rtu.lv/lv/mtaf/par-mums-mtaf/mtaf-zinas/atvert/

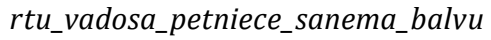

\section{0. jūnijā}

Notiek MLK,F DTI studentu ikgadējā modes skate, kurā studentu darbi tiek prezentēti inovatīvā formātā - īpašā modes īsfilmu ciklā.

https://www.delfi.lv/kultura/news/culturenvironment/foto-modes-diplomdarbiieskats-rtu-dizaina-tehnologiju-studentu-kolekcijas.d?id=53262707

\section{2. jūnijā}

RTU apmeklē Eiropas Komisijas prezidente Urzula fon der Leiena (Ursula von der Leyen) un LR Ministru prezidents Krišjānis Kariņš. Amatpersonas tiekas ar RTU vadību, apmeklē studentu pilsētiņu Ķīpsalā, iepazīstas ar zinātnieku radītajām inovācijām un sniedz preses konferenci.

https://www.rtu.lv/lv/universitate/masu-medijiem/zinas/atvert/ ek-priekssedetaja-rtu-iepazisies-ar-zinatnieku-raditajam-zalajam-tehnologijam

\section{6.-27. jūnijā}

RTU sportisti izcīna Latvijas čempiona titulu vieglatlētikā.

https://www.rtu.lv/lv/sports/sporta-centra-jaunumi/atvert/rtu-sportisti-izcinalatvijas-cempiona-titulu-vieglatletika?fbclid=IwAR2CMqjbgd6zO69KexYuE118cJEn oGwNIrJX15ylSAHPw2zgU3Xq2A0D8hQ 


\section{8. jūnijā}

RTU Senāts pieṇem lēmumu (protokola Nr. 651):

- $\quad$ apvienot MLĶF Silikātu materiālu institūtu, Neorganiskās k̦īmijas institūtu un Funkcionālo materiālu tehnologiju zinātnisko laboratoriju un izveidot Materiālu un virsmas tehnologiju institūtu un apstiprināt jaunizveidotā institūta nolikumu;

- mainīt RTU BIF Būvniecības un rekonstrukcijas institūta nosaukumu uz «Būvkonstrukciju inženierzinātṇu institūts» un nosaka, ka lēmums stājas spēkā 2021. gada 1. septembrī.

\section{Jūnijā}

RTU rektors akadēmiķis Leonīds Ribickis par sasniegumiem elektrotehnikā sañem Polijas Elektroinženieru asociācijas apbalvojumu - Mihaila Doḷivo-Dobrovoḷska medal̦u.

RTU starptautiskajā reitingā «QS World University Rankings 2022» iekḷūst 751.-800. vietā, un šis rādītājs ir augstākais no reitingā iekḷauto trīs Latvijas universitāšu - RTU, RSU un LU - vērtējuma rezultātiem.

https://www.rtu.lv/lv/universitate/masu-medijiem/zinas/atvert/ rtu-latvija-saglaba-liderpozicijas-prestizaja-qs-world-university-rankings-1

Ceturto gadu RTU iekḷauta «Ilgspējas indeksa» augstākajā jeb platīna kategorijā.

https://www.rtu.lv/lv/universitate/masu-medijiem/zinas/atvert/ rtu-saglaba-savas-pozicijas-ilgtspejas-indeksa-platina-kategorija

\section{1. jūlijāà}

AF profesorei Dr. arch. Sandrai Treijai pasniedz LR Izglītības un zinātnes ministrijas Atzinības rakstu par izciliem sasniegumiem, attīstot augstāko izglītību arhitektūrā Latvijā.

https://lvportals.lv/dienaskartiba/330025-dr-arch-sandrai-treijai-pasniedzatzinibas-rakstu-par-sasniegumiem-attistot-augstako-izglitibu-arhitektura-2021

\section{2. jūlijā}

RTU rektors akadēmiḳis Leonīds Ribickis paraksta sadarbības līgumu ar Eiropas Kosmosa aǵentūru par ESA_lab@RTU izveidi, stiprinot universitātes kompetenci kosmosa tehnologiju jomā un veicinot kosmosa un ar to saistīto nozaru izaugsmi.

https://www.rtu.lv/lv/universitate/masu-medijiem/zinas/atvert/rtu-parakstisligumu-ar-eiropas-kosmosa-agenturu?fbclid=IwAR18-MODM2vAIUakVNIIBPtIFxH4 2maKvPkvEa-Syd0yPPSS6GRhRN42fgs 
Desmito gadu pēc kārtas RTU tiek atzīta par darba devēju ieteiktāko augstskolu Latvijā.

https://www.rtu.lv/lv/universitate/masu-medijiem/zinas/atvert/

jau-desmito-gadu-darba-deveji-jauniesiem-iesaka-izveleties-studijas-rtu

Notiek ceturtais RTU IZV izlaidums.

https://www.izv.lv/2021/07/

rtu-inzenierzinatnu-vidusskola-nosvinets-ceturtais-izlaidums/

\section{3. un 4. jūlijā}

Pirmo reizi Baltijas valstu vēsturē trīs reǵiona «EIT Food» centri «AgriFood Lithuania DIH», RTU un Tartu Biotehnologijas parks - kopīgi organizē starptautisku tiešsaistes hakatonu «HACK DigitalSea'21», lai meklētu risinājumus ilgtspējīgas akvakultūras attīstībai Baltijas jūras regionā.

https://www.rtu.lv/lv/universitate/masu-medijiem/zinas/atvert/ notiks-pirmais-digitalas-juras-hakatons-baltijas-valstis

\section{8. jūlijā}

Iemūrē laika kapsulu MATF Aeronautikas institūta zinātniskās pētniecības un mācību angāra pamatos, K,īpsalas ielā 8, Zunda kanāla pusē.

https://www.rtu.lv/lv/universitate/masu-medijiem/zinas/atvert/iemurespamatakmeni-angaram-kura-rtu-zinatnieki-un-studenti-attistis-aeronautikastehnologijas.

MLĶF DTI praktiskā docente Agrita Krievin,a-Siliṇa saṇem konkursaforuma «Sieviete arhitektūrā, būvniecībā un dizainā» balvu «Par ieguldījumu. Sieviete - dizaina veicinātāja 2020».

https://www.buvniekupadome.lv/konkurss/konkursa-foruma-sieviete-arhitekturabuvnieciba-dizaina-2020-rezultati/?fbclid=IwAR1Lin2PsmrMbvDKmwhUfAyeOkOIB 1ASJKPCXVY7DCRIVMGAX3UTCELO-UM

\section{9. jūlijā}

Cēsu Centrālajā bibliotēkā atklāj AF veidoto ceḷojošo izstādi «Jaunie arhitekti - Latvijai». Izstāde ir noslēdzošais pasākums arhitektu izglītības 150 gadu jubilejas sarīkojumu ciklā.

https://www.rtu.lv/lv/af/par-mums/af-zinas/atvert/cesis-skatama-rtuarhitekturas-fakultates-veidota-izstade-jaunie-arhitekti-latvijai-1

\section{7. jūlijā}

Spilves lidlaukā notiek piektais RTU Lielais izlaidums, kurā diplomus saṇem aptuveni 1000 visu fakultāšu un studiju līmeṇu absolventi. Ievērojot epidemiologiskās drošības situāciju un valstī noteiktos 
pulcēšanās ierobežojumus, otro gadu pēc kārtas izlaidums notiek auto jeb drive-in formātā.

https://www.rtu.lv/lv/universitate/masu-medijiem/zinas/atvert/ verienigi-nosvinets-rtu-lielais-auto-izlaidums-2021

\section{7. jūlijā}

Latvijas peldētājs, MTAF 2. kursa maǵistrants Daniils Bobrovs debitē vasaras olimpiskajās spēlēs (Tokijā), izcīnot 31. vietu 200 m brasa distancē, uzrādot laiku 2:14,25.

https://www.delfi.lv/sports/news/vasaras-olimpiskas-speles/zinas/ peldetajs-bobrovs-olimpiskajas-speles-debite-31-pozicija.d?id=53428339

\section{Jūlijā}

IEVF Starptautisko ekonomisko sakaru un muitas institūta bakalaura un maǵistra studiju programmas «Muitas un nodokḷu administrēšana» san,em Eiropas Komisijas atzīšanas sertifikātu.

https://www.rtu.lv/lv/universitate/masu-medijiem/zinas/atvert/eiropas-komisijaatzist-rtu-muitas-izglitibu-novertejot-to-ka-vienu-no-labakajam-eiropas-savieniba

RTU vienīgā no Baltijas augstskolām iekḷūst 40 labāko augstskolu skaitā starptautiskā reitinga «World's Universities with Real Impact» (WURI) sadaḷā, kurā tiek vērtēta augstskolu kapacitāte uzṇēmējspēju veicināšanā un uzṇēmējdarbības vides attīstībā. RTU ierindojas 31. vietā, uzrādot labāko rezultātu ne tikai Latvijā, bet arī Baltijā.

https://www.rtu.lv/lv/universitate/masu-medijiem/zinas/atvert/rtu-vieniga-nobaltijas-ieklust-reitinga-kura-novertets-universitates-ieguldijums-uznemejspejuveicinasana

\section{2. augustā}

Latvija kḷūst par pilntiesīgu Eiropas Kodolpētniecības centra (CERN) asociēto dalībvalsti. Svinīgajā uzṇemšanas pasākumā, kas tiešsaistē norisinās gan CERN mītnē Ženēvā, gan Rīgā, Latvijas Izglītības un zinātnes ministrijā, piedalās izglītības un zinātnes ministre Anita Muižniece, RTU profesors un Latvijas pārstāvis CERN Toms Torims un Ārlietu ministrijas Starptautisko organizāciju un cilvēktiesību departamenta direktore Ilze Rūse. Savukārt CERN Latviju pārstāv Latvijas vēstnieks ANO Ženēvā Bahtijors Hasans, ceremonijā piedalās arī CERN generāldirektore Fabiola Džanoti (Fabiola Gianotti) un citi CERN vadības pārstāvji.

https://www.rtu.lv/lv/universitate/masu-medijiem/zinas/atvert/ latvija-klust-par-pilntiesigu-cern-asocieto-dalibvalsti 


\section{7.-8. augustā}

RTU komanda (IEVF 1. kursa magistrante Viktorija Majorova, DITF 4. kursa studente Diāna Zeltiṇa, RTU Sporta centra direktora vietniece Sanita Sveile un topošā RSU studente Diāna Afanasjeva) izcīna sudraba medaḷu Latvijas komandu čempionāta galda tenisā augstākajā līgā.

https://www.rtu.lv/lv/sports/sporta-centra-jaunumi/atvert/

rtu-galda-tenisistem-sudrabs-latvijas-cempionata-augstakaja-liga

\section{7.-15. augustā}

Starptautiskajā izstāžu centrā Ķīpsalā desmito reizi notiek Ziemel̦eiropā lielākais šaha festivāls «RTU Open 2021», kurā uzvar Vācijas lielmeistars Aleksandrs Dončenko.

https://www.rtu.lv/lv/universitate/masu-medijiem/zinas/atvert/starptautiskajasaha-festivala-rtu-open-2021-uzvar-vacijas-lielmeistars-aleksandrs-doncenko

\section{0.-16. augustā}

46 dalībvalstu un 180 dalībnieku konkurencē RTU IZV skolnieks Džonatans Miks Melgalvis iegūst zelta medaḷu 17. starptautiskajā geogrāfijas olimpiādē, kas šogad norisinājās tiešsaistes režīmā un ko organizēja Turcija.

https://www.visc.gov.lv/lv/jaunums/skolnieks-no-latvijas-izcina-sajastarptautisko-olimpiazu-sezona-pirmo-zelta-medalu?fbclid=IwAR1LcAYR_ZCeHKU hT53Lie00RjRrXWcYTG4QJRHftNjKaw-Mp25kT9L6KxQ

\section{6. augustā}

Stājas spēkā grozījumi Augstskolu likumā, kas paredz augstskolu pārvaldības reformu, mainot augstākās izglītības sistēmas pārvaldību Latvijā un dalot augstskolas jaunā tipologijā.

https://www.delfi.lv/news/national/politics/

stajas-speka-grozijumi-augstskolu-likuma.d?id=53490277

\section{5. augustā}

RTU IZV sesto gadu pēc kārtas iegūst pirmo vietu Ata Kronvalda fonda mazo skolu reitingā un cel̦ojošo balvu «Lielā pūce».

https://www.rtu.lv/lv/universitate/masu-medijiem/zinas/atvert/rtuinzenierzinatnu-vidusskola-apliecina-savu-izcilibu-tradicionali-klustot-par-labakomazo-skolu-latvija

Par ieguldījumu talantīgu skolēnu izglītošanā un skolēnu zinātniskās darbības vadīšanā Valsts prezidents Egils Levits RTU IZV k̦īmijas skolotājai Laurai Fjodorovai pasniedz Ata Kronvalda balvu.

https://www.rtu.lv/lv/universitate/masu-medijiem/zinas/atvert/valsts-prezidentssveic-izv-skolotaju-lauru-fjodorovu-novertejot-ieguldijumu-talantigu-skolenuizglitosana 


\section{8. augustā}

Latvijas XXXI Universiādes sacensībās galda tenisā RTU sieviešu komanda - Viktorija Majorova (IEVF), Liāna Zeltiṇa (DITF), Kristīne Berežkova (BIF) - kopvērtējumā izcīna 1. vietu. V. Majorova un L. Zeltiṇa izcīna uzvaru arī sieviešu dubultspēlēs. Individuālajā vērtējumā vīriešiem par čempionu kḷūst Eduards Spāgis (DITF).

https://www.rtu.lv/lv/sports/sporta-centra-jaunumi/atvert/rtu-sportisti-izcinauzvaras-latvijas-хxxi-universiades-sacensibas- galda-tenisa?fbclid=IwAR3UGANCKA kZbFKhz2AoUKx9V9PRSEZ2mBbldFej7RiGcGcT6iDJpGNOIpM

\section{0. augustā}

Ar RTU Senāta lēmumu (sēdes protokols Nr. 652):

- $\quad$ pamatojoties uz BIF domes 2021. gada 29. jūnija lēmumu (protokols Nr. 011/2021), BIF dekāna amatā apstiprināts Mārtinš̌ Vilnītis;

- jaunā redakcijā apstiprināts RTU Senāta nolikums, noteikta tā spēkā stāšanās kārtība un nolemts to virzīt apstiprināšanai RTU Satversmes sapulcē.

Notiek svinīgais RTU Talantu programmas otrā «iesaukuma» atklāšanas pasākums, kurā piedalās arī RTU Talantu programmas patrons, Eiropas Komisijas priekšsēdētājas izpildvietnieks ekonomikas un finanšu jautājumos Valdis Dombrovskis.

https://www.rtu.lv/lv/universitate/masu-medijiem/zinas/atvert/rtu-talantuprogramma-studijas-uzsak-izcilakie-latvijas-jauniesi?fbclid=IwAR2_FPIbPIj9Bn4DCPSEhRz7-cbT2zgHHtl3XNG218UZ-HyE7cNhABBk4Y

\section{1. augustā}

Rektora akadēmiķa Leonīda Ribicka tradicionālā tikšanās ar RTU mācībspēkiem un darbiniekiem, jauno studiju gadu sākot.

Tiešsaistes pasākums «Startēšu RTU», kurā 1. kursa studenti tiek iepazīstināti ar RTU studiju procesu, zinātniskajām, praktiskajām un ārpusstudiju aktivitātēm.

https://www.rtu.lv/lv/universitate/masu-medijiem/zinas/ atvert/31-augusta-tiessaistes-pasakuma-pirmkursniekus-iepazistinas-ar-rtu

Notiek RTU Satversmes sapulces sēde, kurā apstiprina RTU Senāta nolikumu jaunā redakcijā.

Atzīmējot IEVF 55. gadadienu, dekāne profesore Elīna Gaile-Sarkane tiekas ar fakultātes mācībspēkiem un darbiniekiem, notiek ikgadējais studentu pašpārvaldes pasākums «IEVF lepnums».

https://www.rtu.lv/lv/universitate/masu-medijiem/zinas/atvert/ rtu-inzenierekonomikas-un-vadibas-fakultatei-55 